\title{
ОПИТУВАЛЬНИК БОЙОВОГО СТРЕСУ БЛІНОВА О.А. (ОБСБ)
}

УДК: 159.9.07:355.12(045)

\section{Блінов Олег Анатолійович}

Кандидат психологічних наук, доцент, доцент кафедри сочіальних технологій Національного авіаційного університету, науковий кореспондент лабораторії психологї навчання імені I. О. Синиці Інституту психології імені Г.С. Костюка НАПН України, м. Київ (Украӥна)

\begin{abstract}
Анотація. У статті розглянутий авторський опитувальник психодіагностики бойового стресу. Він призначений: для визначення рівня психологічного стресу в осіб, щзо приймали участь в екстремальних умовах діяльності; наявності ресурсів людини для подолання наслідків травматичного стресу; встановлення ступеня ї̈ пристосованості до дї в умовах загрози для життя. Опитувальник складається з чотирьох субшкал, а саме: субшкали питань визначення гострих стресових розладів (ГСР) і посттравматичних стресових розладів (ПТСР), субшкали ресурсних питань, субшкал зовнішньо і внутрішньо опосередкованих стрес-факторів, які емоиійно впливають на особистість. Наведений текст опитувальника, який складається з 24 питань, а також оціночна п'ятибальна шкала Р. Лайкерта.
\end{abstract}

Ключові слова: опитувальник, бойовий стрес, військовослужбовці, інтегральний показник, діаграма.

Постановка проблеми та їі зв'язок 3 або приводять до її зриву.

\section{важливими практичними завданнями.}

Бойовий стрес - це психічне відображення стресової реакції в результаті впливу факторів бойової діяльності.

Бойовий стрес 3'являється у людини в екстремальних умовах діяльності, яка супроводжується дією потужних зовнішніх і внутрішніх стрес-факторів. Вони несуть загрозу життю людини, негативно впливають на стан іiї здоров'я, знижують ефективність діяльності
Оцінка бойового стресу вимагає використання надійного і компактного психодіагностичного інструментарію для визначення його рівня, а також ресурсів для корекційної роботи.

Сучасні умови потребують створення універсального психологічного інструментарію, який був би спроможний визначати рівень бойового стресу у широкого кола фахівців діяльність яких здійснюється в екстрема- 
льних умовах. Це відноситься не тільки до військовослужбовців Збройних сил, Державної прикордонної служби, Національної гвардії та ін., але і тих, хто виконує професійні обов'язки в умовах загрози для життя - пожежників, фахівців спецпідрозділів поліції, охоронних служб та ін.

\section{Аналіз останніх досліджень і публіка-}

цій. Відповідно до теми нашого дослідження нами було проаналізовано наукові роботи вітчизняних та зарубіжних фахівців присвячених проблемі бойового стресу та його діагностиці.

Було встановлено, що існує різнобічний психологічний інструментарій, який дозволяє здійснювати оцінку впливу стресфакторів, їх впливу на виробничі процеси в організаціях, стану стресу у фахівців та ін., зокрема це розкривається в шкалі організаційного стресу (ШОС) Макліна (в адаптації Н. Е. Водоп'янової), оціночній шкалі стресових подій Холмса-Раге, експрес-діагностиці стану стресу К. Шрайнера та ін. В результаті проведеної роботи було встановлено, що відсутній психологічний інструментарій, який дозволяє здійснювати психодіагностику бойового стресу.

Для розробки опитувальника нам потрібно було визначитися 3 науковим підгрунтям майбутнього психодіагностичного інструментарію. Методологічною основою опитувальника є концепція стресу Г. Сельє; розуміння бойового стресу Р. Абдурахмановим, Л. Китаєво-Смиком,

О. Караяні; концепція «травматичного неврозу» 3. Фрейда; посттравматичних стресових розладів М. Горовіца; розуміння феномену бойової психічної травми М. Решетніковим, С. Литвинцевим, Е. Снедковим, О. Рєзніком; концепція існування і саморозвитку особистості С. Максименко; багатовимірна модель психологічного виживання людини після сильного стресу BASIC Ph M. Лаада та ін.

\section{Виділення невирішених раніше час-} тин загальної проблеми, якій присвячусться стаття. Проведений аналіз існуючого психодіагностичного інструментарію бойового стресу свідчить про відсутність в інформаційному просторі спеціалізованих опитувальників чи тестів, які були б спроможні здійснювати психодіагностику бойового стресу.

Мета статті. Представити авторський інноваційний психодіагностичний інструментарій визначення бойового стресу. Продемонструвати можливості опитувальника комплексно оцінювати бойовий стрес у фахівців, які перебували в екстремальних умовах діяльносTi.

\section{Виклад основного матеріалу дослі-} дження.

Визначені наступні основні етапи роботи $з$ опитувальником:

Встановлення проблеми у військовослужбовців і проведення психодіагностики.

Аналіз відповідей респондентів на запитання.

Оцінка окремих відповідей, аналіз ре- 
зультатів у складі субшкал (об’єднаних питань за одним напрямком), а також співвідношень між шкалами.

Проведення процедури визначення інтегрального показника бойового стресу та його фіксація на відповідній шкалі. Аналіз характеристик розвитку стресу в респондентів.

Визначення психологічного профілю спеціаліста з оформленням графічної частини опитувальника. Проведення його аналізу.

Складання експертного психодіагностичного заключення стану бойового стресу респондента та ознайомлення його з результатами роботи.

Використання інформативних показників ресурсного блоку для здійснення психологічної корекції.

Оцінка бойового стресу (у балах) здійснюється за трьома рівнями, а саме:

Бойовий стрес низької інтенсивності. Вважається таким, коли отримуються результати від 1,0 до 2,66 бала (самий високий рівень адаптованості військовослужбовця до дії стрес-факторів).

Бойовий стрес середньої інтенсивнос$m i$. Результат - від 2,66 до 3,91 бала (середній рівень адаптованості).

Бойовий стрес високої інтенсивності. Результат від 3,91 до 5,0 балів (самий низький рівень адаптованості до дії бойових стресорів).

Розподіл питань опитувальника здійснюється наступним чином.
Субшкала № 1. Призначена для діагностики гострих стресових розладів (ГСР) i посттравматичних стресових розладів (ПТСР); використовуються питання за № 1, 5, 9, 13, 17, 21, 23 (разом 7 питань).

Відповіді, які отримали високу оцінку за цією субшкалою (5 балів) вказують на ймовірність наявності ГСР або ПТСР (залежно від часу з моменту критичного інциденту).

Субшкала № 2. Представлена ресурсним блоком (РБ). Сукупність питань, які розкривають спроможність військовослужбовця долати стресові ситуації на когнітивному, афективному та поведінковому рівнях.

Питання за № 2 характеризує рівень віри людини.

Питання за № 6 характеризує спроможність респондента використовувати афективні та емоційні методи.

Питання за № 10 характеризує соціальність (спілкування) людини.

Питання за № 14 характеризує уяву респондента.

Питання за № 18 характеризує когніції (переконання, розсудливість) спроможність людини використовувати свої ресурси.

Питання за № 22 і № 24 надають характеристику фізичної активності респондента. Всього разом 7 питань.

Питання субшкали № 2 у порівнянні 3 питаннями інших субшкал мають зворотній зміст. Чим вищий рівень ресурсу позитивної спрямованості позначається респондентом 
тим нижча повинна бути бальна оцінка.

Субшкала № 3. Для визначення впливу стрес-факторів, що безпосередньо емоційно впливають на особистість військовослужбовця (ФБЕВ) використовуються питання за № 3, 7, 11, 15, 19 (разом 5 питань).

Субшшала № 4. Для визначення впливу стрес-факторів, що опосередковано емоційно впливають на особистість військовослужбовця (ФОЕВ) використовуються питання за № 4, 8, 12, 16, 20 (разом 5 питань). Питання за № 16, 20 розкривають вплив фізіологічного стану респондента на його самопочуття.

В опитувальнику надані три основні стадії розвитку стресу для поглибленого ознайомлення 3 отриманими результатами. Також пропонується ознайомитися з таблицею змін у психічних сферах особистості (дивись Таблицю А), а також визначити особливості проявів стресових розладів за часовими характеристиками (дивись Таблицю Б),

Перша стадія. Стрес низького рівня у військовослужбовців (від 1,0 до 2,66 бала).

Це аларм-стадія, або «мобілізація по пожежній тривозі», коли відбувається мобілізація адаптаційних ресурсів організму. На цій стадії людина знаходиться в стані напруженості і настороженості. Це, свого роду, підготовка до наступного етапу, тому іноді першу стадію називають «передстартовою готовністю».

Триває від декількох годин до двох діб і включає дві фази:

1) фаза шоку - загальний розлад функцій організму внаслідок психічного потрясін- ня або фізичного пошкодження, у результаті бойової діяльності.

2) фаза «протишоку».

При достатній силі стресора фаза шоку закінчується загибеллю організму, протягом перших годин або днів. Якщо адаптаційні можливості організму здатні протистояти стресору, то настає фаза протишоку, де відбувається мобілізація захисних реакцій організму. Фізично і психологічно людина почувається добре, перебуває в піднесеному настрої.

Жоден організм не може постійно перебувати в стані тривоги. Якщо стресогенний фактор дуже сильний або продовжує свою дію, настає наступна стадія.

Друга стадія. Стрес середнього рівня (від 2,66 до 3,91 бала).

Вона співвідноситься зі стадією резистентності (опору).

Складається зі збалансованого витрачання адаптаційних резервів, підтримується існування організму в умовах підвищених вимог до його адаптаційних можливостей.

Тривалість періоду опору залежить від вродженого потенціалу швидкої адаптації до умов життєдіяльності, стресостійкості людини і від сили діючих стрес-факторів.

Відповідь організму залежить не тільки від дії подразника, в його якості може виступати будь-який предмет, явище або значима інформація, також грають важливу роль внутрішні і зовнішні умови життєдіяльності.

Людина розвиває оптимальну енергію, пристосовуючись до обставин, що змінюють- 
ся. Почуває себе цілком стерпно, хоча вже без душевного підйому, характерного для першої фази. Людина ніби «впрацювалася» і готова до більш-менш тривалого зусилля з подолання труднощів. Однак іноді відчувається, що накопичилася втома. Якщо ж стресор продовжує діяти ще довше, настає третя стадія.

Ця стадія призводить, або до стабілізації стану та одужання, або, якщо стресор продовжує діяти й надалі, змінюється останньою стадією - виснаження.

Третя стадія. Стрес високого рівня (від 3,91 до 5,0 балів).

Співвідноситься зі стадією виснаження (утратою резистентності).

На цій стадії енергія вичерпана, фізіологічний і психологічний захист виявляється зламаним. Існує невідповідність стресогенних впливів середовища і відповідей організму на його вимоги.

Людина не має більше можливості захищатися. На відміну від першої стадії, коли стресовий стан організму веде до розкриття адаптаційних резервів і ресурсів стан третьої стадії більше схожий на «заклик про допомогу», яка може прийти тільки ззовні - або у вигляді підтримки, або у вигляді усунення стресора, що виснажує організм.

Якщо на першій та другій стадії діагностуються деякі ознаки ГСР і ПТСР, то на третій стадії вони об'єднуються вже в цілісний комплекс (синдром).

\section{Інструкція опитувальника бойового}

стресу.

Будь ласка, ознайомтеся із запропонованими питаннями для відповідей. Виберіть такий варіант власної думки із запропонованої п'ятибальної шкали, що найбільш розкриває іiі зміст. В бланку відповідей в кожній колонці праворуч від порядкових номерів позначте вибрану вами цифру:

5 - абсолютно вірно;

4 - скоріше, вірно;

3 - частково вірно, частково невірно;

2 - скоріше, невірно;

1 - абсолютно невірно.

Текст опитувальника:

Моя діяльність проходила в умовах загрози для життя.

У мене немає традицій і ритуалів, яких я люблю дотримуватися.

Несподіваність сприяє виникненню непередбачуваної поведінки.

Моя діяльність в умовах дефіциту часу приводила інколи до негативних наслідків.

Я швидко реагую на різкі звуки, що нагадують травматичні події минулого.

Я рідко відчуваю турботу близьких людей.

Нестандартний перебіг подій задає багато клопоту.

Підвищення мною темпу дій сприяє швидкому розвитку втоми.

Я намагаюся уникати спогадів про травматичні події.

Для мене не важлива взаємна допомога 
Табличя А.

Таблиця змін у психічних сферах особистості

\begin{tabular}{|c|c|c|c|c|}
\hline \multirow{2}{*}{$\begin{array}{l}\text { Рівні стре- } \\
\text { су }\end{array}$} & \multirow{2}{*}{$\begin{array}{l}\text { Характе- } \\
\text { ристика }\end{array}$} & \multicolumn{3}{|c|}{ Психічні сфери } \\
\hline & & Когнітивна & Афективна & Поведінкова \\
\hline Низький & $\begin{array}{c}\text { Розкриття } \\
\text { адаптацій- } \\
\text { них ресур- } \\
\text { сів і резер- } \\
\text { вів }\end{array}$ & $\begin{array}{c}\text { Адекватне оцінюван- } \\
\text { ня обстановки }\end{array}$ & $\begin{array}{c}\text { Здатність управляти } \\
\text { своїми емоціями }\end{array}$ & $\begin{array}{c}\text { Стан «стартової } \\
\text { готовності» і по- } \\
\text { чаток наполегли- } \\
\text { вої служби }\end{array}$ \\
\hline Середній & $\begin{array}{l}\text { Витрати } \\
\text { ресурсів і } \\
\text { резервів }\end{array}$ & $\begin{array}{c}\text { Напружена робота } \\
\text { свідомості } \\
\text { з ознаками втоми у } \\
\text { вигляді проблем з па- } \\
\text { м'яттю, швидкістю } \\
\text { обробки інформації та } \\
\text { ін. }\end{array}$ & $\begin{array}{c}\text { Фіксуються } \\
\text { окремі прояви некон- } \\
\text { трольованих емоцій }\end{array}$ & $\begin{array}{c}\text { Стабільність по- } \\
\text { ведінки } \\
\text { з ознаками легкої } \\
\text { дратівливості, } \\
\text { депресивності } \\
\text { або агресивності) }\end{array}$ \\
\hline Високий & $\begin{array}{c}\text { Потребує } \\
\text { зовнішньої } \\
\text { допомоги } \\
\text { у вигляді } \\
\text { підтримки } \\
\text { або у фор- } \\
\text { мі усунення } \\
\text { стресора, } \\
\text { який ви- } \\
\text { снажує ор- } \\
\text { ганізм }\end{array}$ & $\begin{array}{c}\text { Ознаки професійного } \\
\text { вигорання } \\
\text { (симптоми): } \\
\text { Психофізичні: } \\
\text { відчуття постійної } \\
\text { втоми, часті безпри- } \\
\text { чинні головні болі, } \\
\text { повне або часткове } \\
\text { безсоння } \\
\text { та ін. } \\
\text { Соціально- } \\
\text { психологічні: } \\
\text { байдужість, нудьга, } \\
\text { пасивність і депресія, } \\
\text { підвищена дратівли- } \\
\text { вість, часті нервові } \\
\text { «зриви» } \\
\text { та ін. } \\
\text { Поведінкові: } \\
\text { відчуття, що служба } \\
\text { стає все важчою, а } \\
\text { виконувати їі - все } \\
\text { важче; невіра в пок- } \\
\text { ращення, байдужість } \\
\text { до результатів та ін. }\end{array}$ & $\begin{array}{c}\text { Ознаки емоційного } \\
\text { вигорання } \\
\text { (симптоми): } \\
\text { Фізичні:(фізична } \\
\text { втома, виснаження, } \\
\text { безсоння та ін. } \\
\text { Емоційні: (брак емо- } \\
\text { цій, песимізм, байду- } \\
\text { жність та ін. } \\
\text { Поведінкові: байдуж- } \\
\text { ність до харчування; } \\
\text { нещасні випадки - } \\
\text { падіння, травми, ава- } \\
\text { рії тощо; виправдан- } \\
\text { ня вживання алкого- } \\
\text { лю, ліків та ін. } \\
\text { Інтелектуальні: зни- } \\
\text { ження інтересу до } \\
\text { альтернативних під- } \\
\text { ходів у вирішенні } \\
\text { проблем, апатія, } \\
\text { втрата інтересу до } \\
\text { життя та ін. } \\
\text { Соціальні: низька } \\
\text { соціальна активність, } \\
\text { зниження інтересу } \\
\text { до дозвілля та ін. }\end{array}$ & $\begin{array}{c}\text { Вектор } \\
\text { змін поведінки } \\
\text { від глибокої де- } \\
\text { пресії і загальмо- } \\
\text { ваності } \\
\text { до ауто і зовніш- } \\
\text { ньої агресії на } \\
\text { оточуючих }\end{array}$ \\
\hline
\end{tabular}




\section{Класифікація стресових розладів за часовими характеристиками}

\begin{tabular}{|c|c|}
\hline Гострий стресовий розлад & $\begin{array}{c}\text { Діагностується в період від двох днів до одного місяця } \\
\text { після травматичного інциденту }\end{array}$ \\
\hline $\begin{array}{c}\text { Посттравматичний стресовий роз- } \\
\text { лад }\end{array}$ & $\begin{array}{c}\text { Діагностується не раніше, ніж через місяць. } \\
\text { ПТСР виникає після ГСР або латентного періоду, який } \\
\text { може тривати від кількох тижнів до } 6 \text { місяців або до декі- } \\
\text { лькох років. } \\
\text { Перебіг ПТСР визначається як гострий, коли симптоми } \\
\text { зберігаються впродовж менше трьох місяців, і хронічний, } \\
\text { коли симптоми зберігаються три і більше місяці. У випад- } \\
\text { ках, коли початок симптомів спостерігаєтья через } \\
6 \text { місяців після травматичної події, розлад визначається } \\
\text { як ПТСР з пізнім проявом. }\end{array}$ \\
\hline
\end{tabular}

та підтримка.

Я втрачаю самовладання коли бачу невідповідальність посадових осіб.

Надлишок інформації ускладнює процес адаптації.

Я відчуваю провину за деякі вчинки, що робив раніше.

Імпровізація не моя стихія.

Згадка про діяльність в екстремальних умовах викликає у мене негативні емоції.

Виконання декількох справ одночасно підвищує ризик помилок в управлінні.

Інколи я відчуваю відчуженість до людей.

Для мене не важлива точна оцінка ситуації.

Буває, що я втомлююсь від служби.

Я вважаю, що недостатній рівень злагодженості колективу приводить до зайвих проблем.
Достатньо невеличкої дрібниці, щоб я почав гніватися.

Я не використовую фізичні, дихальні та м'язові практики у боротьбі зі стресом.

Я маю проблеми зі сном.

Для мене немає різниці між фізичною активністю і періодами відпочинку.

Порядок визначення бальної оцінки інтегрального показника бойового стресу здійснюється наступним чином.

Спочатку підраховується загальна кількість балів за всі нараховані бали питань опитувальника. Потім підраховується їх середнє арифметичне значення. Отриманий результат заноситься в бланк відповідей.

На шкалі бойового стресу обводиться кружком, або відзначається цифрою величина інтегрального показника бойового стресу. Вона слугує графічним орієнтиром для аналізу 


\section{Бланк відповідей}

\begin{tabular}{|c|c|c|c|c|c|c|c|}
\hline № 3/ІІ & $\begin{array}{l}\text { Відпо- } \\
\text { відь }\end{array}$ & № 3/II & $\begin{array}{l}\text { Відпо- } \\
\text { відь }\end{array}$ & № 3/ІІ & $\begin{array}{l}\text { Відпо- } \\
\text { відь }\end{array}$ & № $3 /$ II & $\begin{array}{l}\text { Відпо- } \\
\text { відь }\end{array}$ \\
\hline 1 & & 2 & & 3 & & 4 & \\
\hline 5 & & 6 & & 7 & & 8 & \\
\hline 9 & & 10 & & 11 & & 12 & \\
\hline 13 & & 14 & & $\overline{15}$ & & 16 & \\
\hline 17 & & 18 & & 19 & & 20 & \\
\hline 21 & & 22 & & $\sum$ & & $\sum$ & \\
\hline 23 & & 24 & & \multirow{2}{*}{\multicolumn{4}{|c|}{$\begin{array}{l}\text { Розрахунок інтегрального показника } \\
\sum \text { загальн. : } 24=\end{array}$}} \\
\hline$\sum$ & & $\sum$ & & & & & \\
\hline
\end{tabular}

рівня бойового стресу.

Шкала бойового стресу (інтегральний показник) має наступний вигляд:

\section{Шкала бойового стресу:}

$\underline{1,0 \ldots \ldots \ldots .2 .66 \ldots \ldots \ldots \ldots . . \ldots 1 \ldots \ldots \ldots \ldots .0}$

Низький Середній Високий

Робота з графічною частиною організовується наступним чином:

Пропонується вибрати шкалу на діаграмі, яка відповідає вашому номеру питання та обвести на ній кружком цифру відповідно до Вашого вибору. Потрібно з'єднати прямими лініями позначені цифри та здійснити штриховку внутрішньої площини. Ви отримаєте персональний психологічний профіль фахівця, який дозволяє продовжити аналізувати наслідки впливу бойового стресу та знайти ресурси для його корекції.
Відображення психологічного профілю спеціаліста здійснюється в формі наступної діаграми «рози вітрів».

Час на заповнення бланку відповідей та оформлення графічної складової до 20 хв.

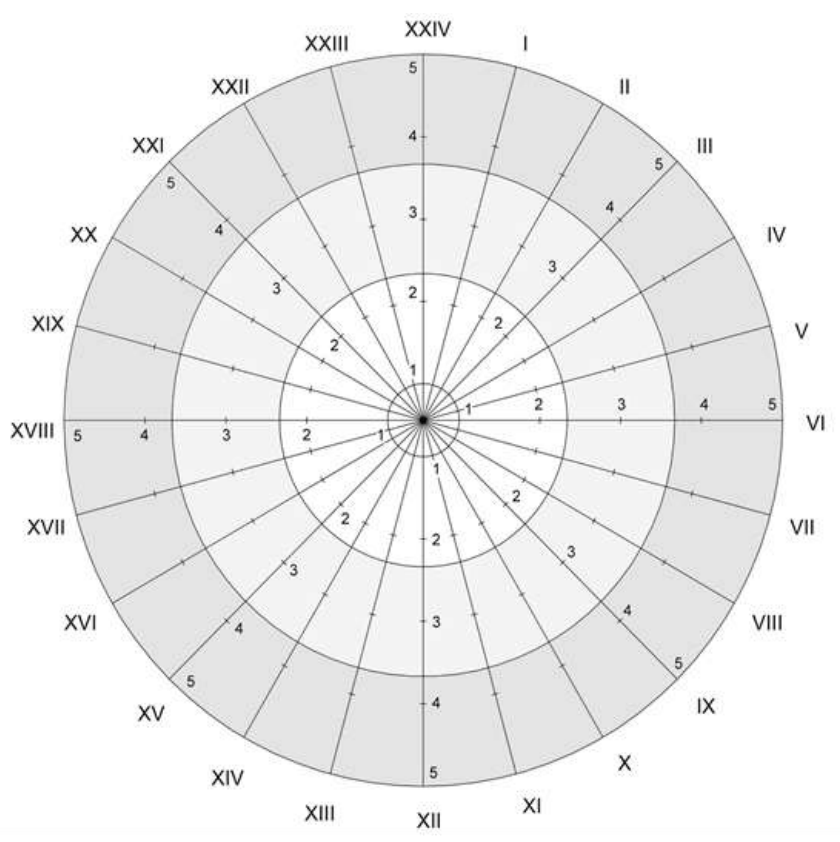

Для встановлення ступеня придатності опитувальника в якості психодіагностичного інструментарію була проведена його апроба- 
ція на 276 військовослужбовцях.

Процедура математичної верифікації проведена в лабораторії екологічної психології Інституту психології імені Г.С. Костюка НАПН України кандидатом психологічних наук, старшим науковим співробітником Верніком Олексійом Леонідовичем.

У результаті проведеної математичної обробки даних встановлено, що коефіцієнт внутрішньої узгодженості субшкал опитувальника за Л. Кронбахом (KR) має наступні рівні:

\begin{tabular}{|c|c|c|c|c|c|}
\hline & Alfa & & & & \\
\hline & All & ATO & $\begin{array}{c}\text { NotA- } \\
\text { TO }\end{array}$ & $\begin{array}{c}\text { Woun } \\
\mathbf{d}\end{array}$ & $\begin{array}{c}\text { Not } \\
\text { Wo } \\
\text { und }\end{array}$ \\
\hline $\begin{array}{c}\text { ГCP } \mathbf{\Pi} \\
\text { TCP }\end{array}$ & 0,71 & 0,8201 & 0,592 & 0,807 & $\begin{array}{c}0,70 \\
3\end{array}$ \\
\hline PБ & 0,59 & 0,668 & 0,52 & 0,526 & $\begin{array}{c}0,60 \\
4\end{array}$ \\
\hline ФБEB & 0,706 & 0,804 & 0,576 & 0,81 & $\begin{array}{c}0,63 \\
7\end{array}$ \\
\hline ФОЕВ & 0,38 & 0,423 & 0,387 & 0,629 & $\begin{array}{c}0,34 \\
6\end{array}$ \\
\hline
\end{tabular}

Де -

ГСР_П Субшкала № 1. Гострі стресові розлади i TCP ${ }^{-}$посттравматичні стресові розлади

РБ Субшкала № 2. Ресурсний блок

ФБЕВ Субшкала № 3. Стрес-фактори, що безпосередньо емоційно впливають на особистість військовослужбовця

ФОЕВ Субшкала № 4. Стрес-фактори, що опосередковано емоційно впливають на особистість військовослужбовця

Alfa/ Загальний показник

All

ATO Військовослужбовці, які проходили службу в АТО

NotA- Військовослужбовці, які не проходили слу-

TO жбу в АТО

Wound Були поранені

NotWo Без поранень
Проведення кореляційних процедур по визначенню внутрішньої узгодженості субшкал опитувальника дало наступні результати.

Субшкала № 1. Гострі стресові розлади і посттравматичні стресові розлади

\begin{tabular}{|c|c|c|c|}
\hline Кількість чол. & 276 & $\begin{array}{c}\text { Стандартне відхил. } \\
(\sigma)\end{array}$ & $\begin{array}{c}5,122 \\
957\end{array}$ \\
\hline Середнє & $\begin{array}{c}18,61 \\
594\end{array}$ & Асиметрія & $\begin{array}{c}0,436 \\
42\end{array}$ \\
\hline Медіана & 18 & Ексцес & $\begin{array}{c}0,171 \\
6\end{array}$ \\
\hline Мода & 17 & $\begin{array}{c}\text { Тест Колмогорова- } \\
\text { Смирнова }\end{array}$ & 1,249 \\
\hline Частота моди & - & $\begin{array}{c}\text { Асимптотична зна- } \\
\text { чимість }\end{array}$ & 0,118 \\
\hline Мінімум & 7 & Низький & 13 \\
\hline Максимум & 34 & Високий & 24 \\
\hline
\end{tabular}

Субшкала № 2. Ресурсний блок

\begin{tabular}{|c|c|c|c|}
\hline $\begin{array}{c}\text { Кількість } \\
\text { чол. }\end{array}$ & 276 & $\begin{array}{c}\text { Стандарт- } \\
\text { не відхил. } \\
(\sigma)\end{array}$ & 4,285028 \\
\hline Середнє & 15,92391 & Асиметрія & 0,548216 \\
\hline Медіана & 16 & Ексцес & 1,060273 \\
\hline Мода & 16 & $\begin{array}{c}\text { Тест Кол- } \\
\text { могорова- } \\
\text { Смирнова }\end{array}$ & 1,62 \\
\hline $\begin{array}{c}\text { Частота } \\
\text { моди }\end{array}$ & - & $\begin{array}{c}\text { Асимпто- } \\
\text { тична зна- } \\
\text { чимість }\end{array}$ & 0,01 \\
\hline Мінімум & 7 & Низький & 12 \\
\hline Максимум & 32 & Високий & 20 \\
\hline
\end{tabular}
und 
Субшкала № 3. Стрес-фактори, що безпосередньо емоційно впливають на особистість військовослужбовця

\begin{tabular}{|c|c|c|c|}
\hline $\begin{array}{c}\text { Кількість } \\
\text { чол. }\end{array}$ & 276 & $\begin{array}{c}\text { Стандартне } \\
\text { відхил. }(\sigma)\end{array}$ & 3,447821 \\
\hline Середнє & $\begin{array}{c}13,8804 \\
3\end{array}$ & Асиметрія & 0,247203 \\
\hline Медіана & 14 & Ексцес & $-0,40255$ \\
\hline Мода & 12 & $\begin{array}{c}\text { Тест Колмого- } \\
\text { рова- } \\
\text { Смирнова }\end{array}$ & 1,56 \\
\hline $\begin{array}{c}\text { Частота мо- } \\
\text { ди }\end{array}$ & - & $\begin{array}{c}\text { Асимптотична } \\
\text { значимість }\end{array}$ & 0,029 \\
\hline Мінімум & 6 & Низький & 10 \\
\hline Максимум & 23 & Високий & 17 \\
\hline
\end{tabular}

Субшкала № 4. Стрес-фактори, що опосередковано емоційно впливають на особистість військовослужбовця

\begin{tabular}{|c|c|c|c|}
\hline $\begin{array}{c}\text { Кількість } \\
\text { чол. }\end{array}$ & 276 & $\begin{array}{c}\text { Стандартне } \\
\text { відхил. }(\sigma)\end{array}$ & 12,16565 \\
\hline Середнє & 63,19203 & Асиметрія & 0,384666 \\
\hline Медіана & 63 & Ексцес & 0,380375 \\
\hline Мода & 64 & $\begin{array}{c}\text { Тест Колмого- } \\
\text { рова-Смирнова }\end{array}$ & 0,885 \\
\hline $\begin{array}{c}\text { Частота мо- } \\
\text { ди }\end{array}$ & 13 & $\begin{array}{c}\text { Асимптотична } \\
\text { Значимість }\end{array}$ & 0,414 \\
\hline Мінімум & 32 & Низький & 51 \\
\hline Максимум & 105 & Високий & 75 \\
\hline
\end{tabular}

Загальна матриця середніх значень за субшкалами має наступний вигляд:

\section{Висновки:}

Бойовий стрес - це психічне відображення стресової реакції в результаті впливу факторів бойової діяльності. Опитувальник бойового стресу Блінова О.А. (ОБСБ) є інноваційним психологічним інструментарієм визначення бойового стресу.

Опитувальник призначений: для визначення рівня бойового психологічного стресу в осіб, що приймали участь в екстремальних умовах діяльності; наявності ресурсів людини для подолання наслідків травматичного стресу; встановлення ступеня ii пристосованості до дії в умовах загрози для життя.

Опитувальник складається 324 питань оцінка яких здійснюється за 5-бальною шкалою Р. Лайкерта.

В опитувальнику є графічна складова у вигляді Шкали інтегрального показника бойового стресу, а також діаграми «рози вітрів» психологічного профіля спеціаліста.

Математична верифікація опитувальника засвідчила високу прогностичну цінність та перспективність його використання.

\section{Перспективи подальших розвідок у} даному напрямі. На наш погляд, подальше наукове вивчення бойового стресу потребує перекладу опитувальника на російську мову 3 наступною його апробацією.

\begin{tabular}{|c|c|c|c|c|c|}
\hline У 5-бальній шкалі & ГСР_ПТСР & РБ & ФБЕВ & ФОЕВ & Загалом \\
\hline Низький & 2,17 & 2,00 & 2,75 & 2,50 & 2,66 \\
\hline Високий & 4,0 & 3,33 & 4,50 & 4,25 & 3,91 \\
\hline Центр & 3,10 & 2,65 & 3,69 & 3,47 & 3,29 \\
\hline
\end{tabular}




\section{Список використаних джерел:}

1. Блінов О. А. Психологія бойової психічної травми : монографія / О. А. Блінов. - К. : Талком, 2016. - 246 с.

2. Кадыров $P$. $\quad B$. Посттравматическое стрессовое расстройство (PTSD): состояние проблемы, психодиагностика и психологическая помощь : учебное пособие / Р. В. Кадыров. - СПб.: Речь, 2012. - 448 с.

3. Караяни А. Г. Настольная книга военного психолога: практич. пособие / А. Г. Караяни. - М.: Издательство Юрайт, 2016. - 332 с. - Серия: Профессиональная практика.

4. Максименко С. Д. Генезис существования личности. - К. : Издательство ООО «КММ», 2006. - 240 с.

5. Клінічні рекомендації щодо застосування методів психодіагностики та медико-психологічної реабілітації у лікарняних та санаторно-курортних закладах Міністерства оборони України / Мех П.І., Казмірчук А.П., Швець А.В., Кіх А.Ю., Ричка О.В., Чайковський А.Р., Іванцова Г.В., Блінов О.А. / під заг. ред. професора, доктора медичних наук В.В. Стеблюка та доктора медичних наук А.М. Галушки. - К., 2017. - 266 с.

6. Уніфікований клінічний протокол первинної, вторинної (спеціалізованої) та третинної (високоспеціалізованої) медичної допомоги. Реакція на важкий стрес та розлади адаптації. Посттравматичний стресовий розлад / В. В. Кравченко, І. Я. Пінчук, І. А. Марценковський та ін. - К. : Державний експертний центр Міністерства охорони здоров'я України, 2016. - 57 с.

7. Лаад М. Многомерная модель внутренней устойчивости BASIC PH [Електронний ресурс]. - Режим доступу : http://stat.haifa.ac.il/ pavelg/downloads/ BASIC $\%$ 20PH.pdf

\section{References (Transliteration):}

1. Blinov O. A. Psihologija bojovoï psihichnoï travmi : monografija / O. A. Blinov. - K. : Talkom, 2016. - 246 s.

2. Kadyrov R. $\quad$ V. Posttravmaticheskoe stressovoe rasstrojstvo (PTSD): sostojanie problemy, psihodiagnostika i psihologicheskaja pomosh : uchebnoe posobie / R. V. Kadyrov. - SPb. : Rech, 2012. - 448 s.

3. Karajani A. G. Nastolnaja kniga voennogo psihologa : praktich. posobie / A. G. Karajani. - M. : Izdatelstvo Jurajt, 2016. - 332 s. - Serija : Professionalnaja praktika.

4. Maksimenko S. D. Genezis sushhestvovanija lichnosti. K. : Izdatelstvo OOO «KMM», 2006. - $240 \mathrm{~s}$.

5. Klinichni rekomendaciï shhodo zastosuvannja metodiv psihodiagnostiki ta mediko-psihologichnoï reabilitaciï $\mathrm{u}$ likarnjanih ta sanatorno-kurortnih zakladah Ministerstva oboroni Ukraïni / Meh P.I., Kazmirchuk A.P., Shvec A.V., Kih A.Ju., Richka O.V., Chajkovskij A.R., Ivancova G.V., Blinov O.A. / pid zag. red. profesora, doktora medichnih nauk V.V. Stebljuka ta doktora medichnih nauk A.M. Galushki. - K., 2017. - 266 s.

6. Unifikovanij klinichnij protokol pervinnoï, vtorinnoï (specializovanoï) ta tretinnoï (visokospecializovanoï) medichnoï dopomogi. Reakcija na vazhkij stres ta rozladi adaptaciï. Posttravmatichnij stresovij rozlad / V. V. Kravchenko, I. Ja. Pinchuk, I. A. Marcenkovs'kij ta in. - K.: Derzhavnij ekspertnij centr Ministerstva ohoroni zdorov'ja Ukraïni, 2016. - 57 s.

7. Laad M. Mnogomernaja model' vnutrennej ustojchivosti BASIC PH [Elektronnij resurs]. - Rezhim dostupu : http:// stat.haifa.ac.il/ p pavelg/downloads/ BASIC\%20PH.pdf

\section{Blinov Oleg}

PhD in Psychology, Associate Professor, Scientific Correspondent at the Laboratory of Educational Psychology named after I.O. Sinitsy, Institute of Psychology named after G.S. Kostiuk, National Academy of Pedagogical Sciences in Ukraine, Kiev (Ukraine)

\section{COMBAT STRESS QUESTIONNAIRE DESIGNED BY O. BLINOV (QCSB)}

\section{ABSTRACT}

The psychological and diagnostic combat stress questionnaire designed by the author is considered in the article. It can be used for: determining the level of psychological stress among 
people who took part in extreme activities; identifying resources to overcome the consequences of traumatic stress; establishing the degree of personal adaptability in conditions which threaten life. The contents of the questionnaire, the stages of work, the characteristics of the subclasses and the distribution of the questions are represented. It has been found that assessment of the combat stress (valued in in scores) can be carried out through the following three levels. The questionnaire consists of the following four subscales: identifying acute stress disorders (ASD) and posttraumatic stress disorders (PTSD), resource issues, external and internal stress factors emotionally affected people. The outline of the questionnaire (24 questions) and R. Lickert's five-point scale, which reveals the peculiarities of personal opinion on combat stress are presented. The main stages of stress development, as well as personal changes at cognitive, emotional and behavioral levels, which can be considered as a result of the influence of stress factors, are identified. The sequence of determining the integral indicator of combat stress, managing the scale of combat stress and graphic design of psychological profile for specialists are described. The psychological profile of a specialist is created using the chart's capabilities. The results of correlation analysis between the structural components of the questionnaire are shown.

Key words: questionnaire, combat stress, military personnel, integral index, diagram.

\section{Блинов Олег Анатолиевич}

Кандидат психологических наук, доиент, доиент кафедры сочииальных технологий Национального авиационного университета, научный корреспондент лаборатории психологии обучения имени И. О. Синицы Института психологии имени Г.С. Костюка НАПН Украины, г. Киев (Украина)

\section{ОПРОСНИК БОЕВОГО СТРЕССА БЛИ- HOBA O.A. (ОБСБ)}

Аннотация. В статье рассматривается авторский опросник психодиагностики боевого стресса. Он предназначен: для определения уровня психологического стресса у лиц, которые принимали участие в экстремальных условиях деятельности; наличия ресурсов у человека для преодоления последствий травматического стресса; установления степени его приспособленности к действию в условиях угрозы для жизни. Опросник состоит из четыpex субшкал, а именно: субшкалы определения острых стрессовых расстройств и посттравматических стрессовых расстройств, субшкалы ресурсных вопросов, субшкал внешне и внутренне опосредованных стрессфакторов, которые эмоционально влияют на личность. Изложенный текст опросника, который состоит из 24 вопросов, а также оценочная пятибалльная шкала Р. Лайкерта.

Ключевые слова: опросник, боевой стресс, военнослужащие, интегральный показатель, диаграмма.

Дата отримання статті: 19.10 .2017 Дата рекомендації до друку: 21.10.2017 